\title{
37. Rusça-Türkçe dilleri arasında deyimlerin çevirilerine ilişkin sorunlar
}

\section{Jale COȘKUN}

APA: Coşkun, J. (2021) Rusça-Türkçe dilleri arasında deyimlerin çevirilerine ilişkin sorunlar. RumeliDE Dil ve Edebiyat Araştırmaları Dergisi, (Ö9), 473-482. DOI: 10.29000/rumelide.983927.

Öz

Dil insan uygarlığının oluşması ve gelişmesinde en önemli unsurlarından biridir. İnsanlar dil aracılığıyla birbirleriyle ilişki kurar ve yine dil aracılığıyla çevrelerindeki dünyanın bilgisine ve bu bilgiyi biriktirme olanağına sahip olurlar. Diller arasındaki iletişim çeviri sayesinde gerçekleşir. Çeviri bir tür dillerin buluşma etkinliğidir. Geçmişten günümüze kültürler arası iletişim çeviri yolu ile sağlanmış ve sağlanmaya devam etmektedir. Çeviri etkinliğinde deyim çevirisinin özel ve özgün bir yeri vardır. Deyimler, bir dilin zenginliğini sağlayan en önemli dilsel yapıları arasındadır. Duyguların, düşüncelerin en çekici, en özlü anlatımını sağlayan dilsel öğelerin en ön sırasında yer alırlar. Her dilin sahip olduğu deyim varlığı, o dili konuşan toplulukların dünya görüşünü, ulusal kültürünü, geleneklerini, inançlarını ve bütün tarihini yansıtan en değerli bir dilsel miras, bir tür "mikro metin" lerdir. Deyimlerin varlığı, dile canlılık, renklilik ve esneklik kazandırır. Bu nedenle, deyimleri çevirirken, deyimin sadece kavramsal anlamını değil, aynı zamanda onun mecazi anlamını da okuyucuya iletebilmek çok önemlidir. Deyim çevirisi, söz konusu deyimi, erek dilde tam karşılığının olup olmadığını çözümleyerek, en doğru şekilde yorumlama becerisi gerektirir. Bu yapılamazsa çeşitli çeviri sorunlarıyla karşılaşılacak demektir. Deyim çevirisi, modern çeviri teorisi çerçevesinde geliştirilen en güç ve ilginç bir çeviri etkinliğidir. Bu güçlüklerin başlıca nedenlerinden biri, semantik yapılarının karmaşıklığıdır. Bu çalışmanın amacı, deyimlerin birebir çevirisinin hangi hatalara neden olabileceğini göstermek, deyim çevrilmesinde karşılaşılan sorunlara değinmek, kültürlerarası farklılıklardan dolayı öğrencilerin zorluk çektikleri deyim çeviri güçlüklerini aşmada onlara yardımcı olmak, Rusça Mütercim Tercümanlık bölümü öğrencisi olan ya da ana dili Türkçe olup Rusça öğrenen bütün öğrencilere, incelenen deyimleri daha iyi anlama ve yerinde kullanma becerisi kazandırmaktır.

Anahtar kelimeler: Dil, çeviri sorunları, Rusça deyimler, Türkçe deyimler

\section{Problems of idiom translation between Russian and Turkish languages}

\begin{abstract}
Language is one of the most important element for the formation and development of human civilization. Humans contact each other through language, and again through language, they acquire the knowledge of the world around them and have the opportunity to accumulate this knowledge. Communication between languages occurs through translation. Translation is a kind of activity where languages meet. To this day, cross-cultural communication has been enabled through translation and continues to be so. Idiom translation has a special and distinctive place in the translation activity. Idioms are among the most vital linguistic structures that provide the wealth of a language. They are the most prominent linguistic elements that provide attractive and concise expression of emotions and thoughts. The idiom vocabulary that each language has is a kind of "microtext" and the most valuable linguistic heritage that
\end{abstract}

1 Dr. Öğr. Üyesi, İstanbul Aydın Üniversitesi, Yabancı Diller Yüksekokulu, Rusça Mütercim Tercümanlık Bölümü, (İstanbul Türkiye), jalezaman@aydin.edu.tr, ORCID ID: 0000-0003-2013-1190, [Araştırma makalesi, Makale kayıt tarihi: 25.07.2021kabul tarihi: 20.08.2021; DOI: 10.29000/rumelide.983927]

Adres | Address

RumeliDE Dil ve Edebiyat Araştırmaları Dergisi Osmanağa Mahallesi, Mürver Çiçeği Sokak, No:14/8 Kadıköy - ISTANBUL / TÜRKIYE 34714 e-posta: editor@rumelide.com tel: +90 $5057958124,+902167730616$

RumeliDE Journal of Language and Literature Studies Osmanağa Mahallesi, Mürver Çiçeği Sokak, No:14/8

Kadıköy - ISTANBUL / TURKEY 34714

e-mail: editor@rumelide.com,

phone: +90 5057958124 , +90 2167730616 
reflects the worldview, national culture, traditions, beliefs and the entire history of the communities who speak that language. The presence of idioms gives the language vitality, colourfulness and flexibility. Therefore, when translating idioms, it is crucial to be able to convey to the reader not only the conceptual meaning of the idiom but also its metaphorical meaning. Idiom translation requires the ability to interpret that idiom most accurately by analyzing whether it has an equivalent in the target language. If this cannot be done, it means that various translation problems will be encountered. Idiom translation is the most powerful and interesting translation activity developed within the modern translation theory. One of the main reasons for these difficulties is the complexity of the idioms' semantic structure. This study aims to show the errors which the literal translation of idioms might cause, mention the problems encountered while translating idioms, assist the students in overcoming difficulties of idiom translation that occur due to cross-cultural differences, help the students of the Russian Translation and Interpreting department or those with Turkish as a native language and learning Russian acquire a better understanding of the idioms examined and the ability to use them correctly.

Keywords: Language, translation problems, Russian idioms, Turkish idioms

\section{Giriş}

Dil insan uygarlığının oluşması ve gelişmesinde en önemli unsurlarından biridir. İnsanlar dil aracilığıyla birbirleriyle ilişki kurar ve yine dil aracılığıyla çevrelerindeki dünyanın bilgisine ve bu bilgiyi biriktirme olanağına sahip olurlar. Diller arasındaki iletişim çeviri sayesinde gerçekleşir.

Çeviri bir tür dillerin buluşma etkinliğidir. Dille doğrudan bağlantılı olması ve bunun sonucunda toplumların kültürel gelişimine doğrudan katkı sağlaması nedeniyle çeviri insanlı tarihi boyunca en ilgi çekici konulardan biri olarak yerini korumuştur. Çeviri diğer toplumlarla aramızdaki dilsel ve kültürel sınırları aşmamıza yardımcı olur ve dolayısıyla farklı kültürler arasında iletişimi mümkün kılar. (İli, 2015:113) Geçmişten günümüze kültürler arası iletişim çeviri yolu ile sağlanmış ve sağlanmaya devam etmektedir. Çevirinin her türü yaratıcı bir etkinliktir. Bilginin yanı sıra hayal gücü ve zekâ gerektirir.

Çeviri, insanlık tarihinin başlangıcından günümüze kadar uzanan, farklı toplulukların uğraştı̆̆ı bilim, sanat, düşünce alanlarına da hâkim olma imkânı veren, farklı kültür dokularını birleștiren, bilgi aktarımı ve paylaşımında aslında insanların hayatını kolaylaştıran ve bu aktarımı yaparken aktarılan dildeki eşdeğerliği dikkate alan ortak bir dildir (Yalçın \& Büyüksaraç, 2017: 818).

Vardar'ın ifade ettiği gibi çeviri "bütün çağlarda karşımıza çıkan bir etkinlik, çeşitli uygarlıklar arasında köprü kuran, değişik toplumlardan bireyleri birbirine yaklaştıran, her türden ekinsel değeri içinde oluşturduğu tarihsel-toplumsal çevrenin dışına taşıyan, o çevreden olmayan kişilerin yararlanmasına sunan, uygarlıklar ekinler arası bir iletişim, bildirişim aracıdır" (Vardar,1982: 18).

Göktürk ise çeviriyi; “Her dil, belli bir kültürün göstergeler dizgesiyle, belli uzlaşımlar, töreler, davranışlar, değer ölçüleriyle, kısacası somut insan yaşamıyla iç içedir. Değişik toplulukların, ulusların, bilim, sanat, düşünce alanındaki çabalarını birbiriyle paylaşabilme yoludur" şeklinde tanımlamaktadır (Göktürk, 2013:15). Yücel tarafından verilen tanıma göre çeviri, yabancı bir dilin sınırlarını aşarak kaynak dili bilmeyen insanlar için çeviri "olanaksızlı̆ı"” bir anlamda ortadan kaldırmaya çalışan bir araçtır. (Yücel, 2013: önsöz).

Çeviri, karmaş̧ı ve çok yönlü bir insan eylemidir. Genellikle sözü edile "bir dilden başka bir dile" çevirmek olsa da, gerçekte çeviri sürecinde bir dilden bir başka dile aktarımdan daha fazlası vardır. Çeviride, farklı

\section{Adres | Address}

RumeliDE Dil ve Edebiyat Araştırmalar Dergisi $\quad$ RumeliDE Journal of Language and Literature Studies

Osmanağa Mahallesi, Mürver Çiçeği Sokak, No:14/8 Osmanağa Mahallesi, Mürver Çiçeği Sokak, No:14/8

Kadıköy - İSTANBUL / TÜRKIYE 34714 Kadıköy - ISTANBUL / TURKEY 34714

e-posta: editor@rumelide.com e-mail: editor@rumelide.com,

tel: +90 505 7958124, +90 2167730616 phone: +90 505 7958124, +90 2167730616 
kültürler, farklı farklı kişilikler, farklı zihniyetler, farklı edebiyatlar, farklı çağlar, farklı gelişim düzeyleri, farklı gelenekler ve tutumlar karşılaşır. Çeviri konusu kültürologların, etnografların, psikologların, tarihçilerin, edebiyat bilimcilerinin ilgi alanındadır. Bu nedenle de çeviri etkinliği bütün yönleriyle tüm bu bilimsel disiplinlerin başlıca çalışma konuları arasındadır.

\section{Deyimler}

Deyimler, bir dili zenginliğini sağlayan en önemli dilsel yapılardandır. Kısa ve etkili anlatım araçlarıdır. Duyguların, düşüncelerin en çekici, en özlü anlatımını sağlayan dilsel öğelerin en ön sırasında yer alırlar. Bir dilin sahip olduğu deyim varlğ̆ı, o dili konuşan toplulukların dünya görüşünü, ulusal kültürünü, geleneklerini, inançlarını ve bütün tarihini yansıtan en değerli bir dilsel miras, bir tür "mikro metin" lerdir. Onların varlığı, dile canlılık, renklilik ve esneklik kazandırır. Deyimlerin dünyası çok büyüktür, yüzyıllar boyunca insan varlığının ve eylemlerinin tüm alanlarını ve anlamsal olarak, o dili ana dil olarak konuşanların dünya görüşünü ortaya koyar. Deyimler; değerlendirme, tavsiye, kişiyi harekete geçirme, öneri, herhangi bir olgu ve eylemin kesinliği gibi özelliklere sahiptir (Coşkun, 2020: 147).

Deyimler "hazır düşünceler hakkında bilim" (Teliya, 1966: 18), eski kültürlere ait gelenek ve görenekleri öğreten öğretmen gibidir. (Maslova, 2007: 87).

"Bir dilin söz varlığı denince, yalnızca, o dilin sözcüklerini değil, deyimlerin, kalıp sözlerin, kalıplaşmış sözlerin, atasözlerinin, terimlerin ve çeşitli anlatım kalıplarının olușturduğu bütünü anlıyoruz." (Aksan, 1996: 7). "Deyimler, dilin iki veya daha fazla öğeden oluşan biçim, yapısal ve anlamca değişikliğe izin vermeyen donuk örnekleridir" (Şanskiy, 1969: 28).

Mehmet Hengirmen, deyimi "Genellikle gerçek anlamının dışında kullanılan, anlatımı daha güzel ve etkili yapan, toplum tarafından ortak olarak benimsenen kalıplaşmış söz" biçiminde tanımlamıştır (Hengirmen, 1999: 116). Pek çok deyim, dilin tek bir sözvarlığı sistemi çerçevesinde, eş anlamlı karşllıkları olan ayrı sözcükler kadar sık kullanılır. Çünkü bunlardan bazıları, genellikle olup bitenleri ifade etmek için tek bir araç olarak kullanılır.

"Asıl anlamları dışında kullanılan sözcüklerden oluşan deyimler adeta onları kullanan toplumların kültür hayatlarının aynası durumundadır. Bir yandan bazen dünyaları bile anlatabilen bu küçücük dil birimleri, onları kullanan insanların tutum ve davranışlarını, fiziksel ve ruhsal niteliklerini, inanış ve düşünce biçimlerini, kısaca maddi ve manevi kültürlerini yansıtırken, diğer yandan bu ufacık dil unsurları vasıtasıyla sayısız benzetmeler, değişik aktarmalar, çeşitli mecazlar ve etkili anlatım ustalıkları sunulabilmektedir" (Aygün, 2003: 72).

$\mathrm{Bu}$ nedenlerle de deyimlerin doğru ve iyi öğrenilmesi ve çeviri etkinliğinde amaç dile doğru olarak aktarılması gerekir.

Türk ve Rus dilleri arasında deyim çevirisinin başlıca sorunları nelerdir?

Çalışmamızın amacı bu sorunun yanıtlarını aramak, deyimlerin sözcük karşlıklarıyla birebir çevirisinin ne gibi hatalara neden olabileceğini göstermek, deyim çevrilmesinde karşılaşılan başlıca sorunlara değinmek, kültürlerarası farklılıklardan dolayı öğrencilerin zorluk çektikleri deyim çeviri güçlüklerini aşmada onlara yardımcı olmaktır.

\section{Deyimlerin çeviri sorunları}

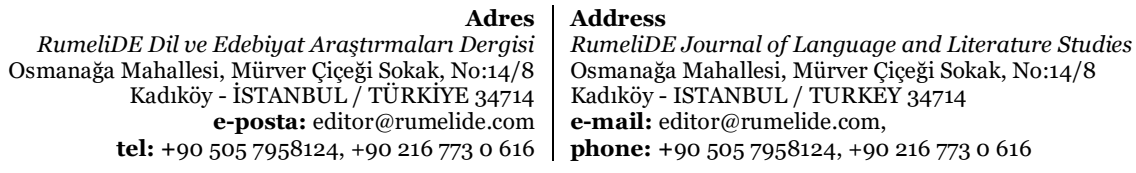




\section{1) Mecazi anlam tașımayan deyimler}

Çeviri etkinliğinde deyim çevirisinin özel ve özgün bir yeri vardır. Deyimleri çevirirken, sadece kavramsal anlamı değil, asıl olarak onun mecazi anlamını okuyucuya iletebilmek gerekir. Deyim çevirisi, söz konusu deyimi, erek dilde tam karşılı̆̆ının olup olmadığını çözümleyerek, en doğru şekilde yorumlama becerisi gerektirir. Bu yapılamazsa çeşitli çeviri sorunlarıyla karşılaşılacak demektir. Deyim çevirisi, modern çeviri teorisi çerçevesinde geliştirilen en güç ve ilginç bir çeviri etkinliğidir. Bu güçlüklerin başlıca nedenlerinden biri, semantik yapılarının karmaşıklığıdır.

Deyimler çoğunlukla, eşdeğeri olmayan ya da tam olarak bir eşdeğere sahip olmayan dil birlikleri olarak saylmaktadırlar, bu nedenle çoğu durumda, kelimesi kelimesine çevrilemezler.

Çevirmen, anadilinin yanı sıra çeviriyi yapacağı erek dillerin ve onların ait oldukları kültürel yapıları özümsemiş olmalıdır. Kaynak metinden fazla uzaklaşmadan erek dile yaklaşmalı, metne bağlılık ve metinden ayrılmamanın kesişme noktasını bulmalıdır (Demirezen, 1991: 126).

Elbette, çevirmen deyim çevirisinde hedef aldığı dilde karşılıklı deyimini bulmaya çalışmalıdır ama hedef alınan dilde eşdeğer bulunmama olasılığı da söz konusudur. 0 zaman yapılması gereken en yakın anlamı bulmaya çalışmaktır.

Deyim çevirisi alanında en az güçlük çıkaracak olanlar, mecazi anlam taşımayan ifadelerin çevirisidir. Bunlar genel olarak kelimesi kelimesine yapılabilecek çevirilerdir. Anlamsal, biçimsel ve leksikal açıdan tam eșdeğerler deyimlerdir. Bu tür deyimler, tercüme edildiği zaman kaynak dildeki anlam ve biçim özelliklerini hedef dilde de korumaktadırlar.

Örneğin,

«хранить молчание» (hranit' molçanie) - susmak, suskunluğunu korumak

«от всего сердца» (ot vsego serdtsa) - candan, gönülden, bütün kalbiyle

«сдержать слово» (sderjat' slovo) - sözünӥ tutmak

«время от времени» (vremya ot vremeni) - zaman zaman

«nервый шаг» (pervıy şag) - ilk adım, ilk hamle

«вбивать в голову» (vbivat' v golovu) - kafasina sokmak

«взвешивать свои слова» (vzveșivat' svai slova) - sözlerini tartmak, lafinı bilmek

«войти в историю» (vayti v istoriyu) - tarihe geçmek

«проглотить язык» (proglatit' yazık) - dilini yutmak

«сложить голову» (slajit' golovu) - baş koymak

«играть с огнем» (igrat's agnyom) - ateşle oynamak

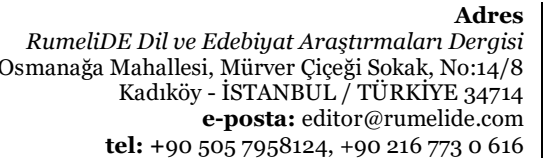

RumeliDE Dil ve Edebiyat Araştırmaları Dergisi Kadiköy - ÍSTANBUL / TÜRKIY tel: +90 505 7958124, +902167730616
Address

RumeliDE Journal of Language and Literature Studies

Osmanağa Mahallesi, Mürver Çiçeği Sokak, No:14/8

Kadıköy - ISTANBUL / TURKEY 34714

e-mail: editor@rumelide.com,

phone: +90 5057958124, +90 2167730616 
«голодный как волк» (galodnıy kak volk) - kurt gibi aç

«взвешивать свои слова» (vzveşivat' svai slova) - sözlerini tartarak konuşmak, lafinı bilmek

«гора родила мышь» (gora radila mış) - dağ fare doğurdu

«лить крокодиловы слёзы» (lit' krakadilovı slyozı) - timsah gözyaşları dökmek

«открывать сердце» (atkrıvat’ serdtse) - kalbini açmak

«проглотить язык» (praglatit' yazık) - dilini yutmak

«не верить своим глазам» (ne verit' svaim glazam) - kendi gözlerine inanamama

«как кошка с собакой» (kak koşka s sabakoy) - kedi köpek gibi vb...

Deyimlerde eşdeğer ve benzer bir ifadenin bulunmaması durumunda, deyimlerdeki ifadenin birebir çeviri olarak diğer dile aktarılma tekniği uygulanır. Örneğin, Türkçedeki "aralarından su sızmamak" deyimi aktarma tekniği ile Rusçadaki «водой не разольёшь» (vadoy ne razalyöş') (birebir çevirisi; aralarına su dökülmez) deyimiyle tam karşılığını bulmaktadır. Bu tür çeviri, yalnızca kaynak metnin yeterince şeffaf olduğu ve çeviri sonrası anlamı tam anlamıyla aktarılabildiği durumlarda uygulanır. Aktarma tekniği, kaynak metni anlam veya üslup olarak değiștirmeden diğer bir dile iletimini sağlar. Aktarma yöntemi, deyim anlamının ulusal-etnik bileşenini iletmek amacıyla yaygın olarak kullanılmaktadır. Fakat deyimlerin milli değerlerini aktarırken de son derece dikkatli davranılması gerekmektedir.

Çoğu zaman çevirmenler, deyimleri çevirirken eşdeğer seviyesinde kelimeler kullanmak yerine, anlam ve üslup olarak onlara en yakın olan, daha basit veya açıklayıcı ifade şekillerini kullanmak zorunda kalabiliyorlar.

Örneğin, Türkçe, “Başa baş” (birebir çevirisi: «голову за голову» (golovu za golovu)) deyimi Rusçada «Баш на баш» - (baş na baş) olarak ifade edilir 1) tam olarak o kadar; 2) tam, üstü kalmayacak şekilde kullanılmıştır.

\section{2) Mecazi anlamı olan deyimler}

Söz konusu deyimin hedef dil okuyucusu tarafından anlaşılabilmesi için çevirmenin yapması gereken ilk şey bu deyimi yorumlamak ve onun derin yapısını çözmektir (Suçin,2013: 190). Sonraki aşamada ise deyimin hedef dilde karşılayan bir deyimin bulunup bulunmadığını araştırmaktır.

Mecazi anlam taşıyan deyim çevirisinde çevirmen kimi kez büyük zorluklarla karşılaşabilir. Bu tür deyimler, genellikle bir öykü, efsane ya da olaydan kaynaklanır.

Bu konuya ilişin olarak da bir örnek verelim:

Rus dilindeki 'седьмая вода на киселе' (sed'maya voda na kisele) - çok uzak akraba anlamında bir deyimdir. Birebir çeviri yapılacak olursa "jöle üstündeki yedinci su” demek gerekir ve Türkçede bunun bir anlamı yoktur. (Söz konusu deyim, içinde bulunduğu metne göre de değerlendirilerek, Türkçeye belki "tavşanın suyunun suyu" olarak çevrilebilir. Rusçada bu deyimin oluşum öyküsü ise Rus mutfağında jöleden

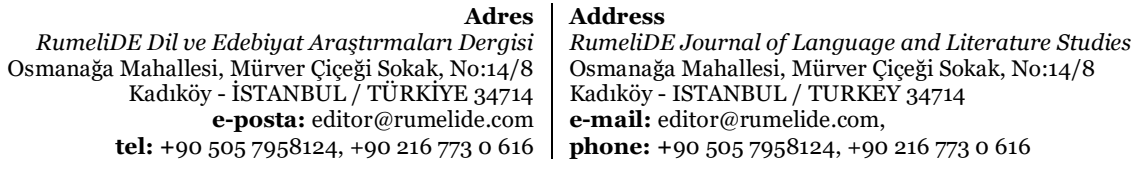


içecek yapılması sürecinde jöle ne kadar çok yıkanırsa suyun o kadar az ortaya çıkmasıyla, birinci ve yedinci su arasındaki farkın çok büyük olmasıyla ilgilidir.

Aşağıda ise Türkçede mecazi anlam taşıyan bazı deyimlerin Rusçada karşılıkları verilmektedir. Bu gibi deyimlerin çevirisinde çevirmen kaynak dildeki deyiminin hedef dildeki karşıllı̆ının bulmaya çalışmalı, bunu başarabilmek içinse her iki dilin kültürel alt yapısı konusunda bilgi sahibi olmalıdır. Aksi halde yanlış ve çoğu kez asıl anlamla ilgisi bulunmayan mantık dışı sonuçlar ortaya çıkacaktır.

göz boyamak - «втирать очки» (vtirat' açki)

baştan savma - «как попало» (kak papalo)

laf kalabalı̆̆ уартаk - «вешать лапшу на уши» (veşat' lapşu na uşi)

tecrübesiz, асеті - «желторотый птенещ» (jöltorotnly pteneç)

kurnaz - «лиса Патрикеевна» (Lisa Patrikeyevna)

çok uzak, dünyanın bir ucunda bulunmak, yaşamak - «у чёрта на куличках» (и çуorta na kuliçkah)

onun ipiyle kuyuya inilmez - «каши не сваришь» (kași ne svariş)

tencere yuvarlanmış kapağını bulmuş - «два canoza napa» (dva sapaga para)

burnunun dibinde bitmek - «как из-под земли вырос» (kak iz pod zemli vıros)

mükemmel insan - «белая ворона» (belaya varona)

bol şanslar - «ни пуха ни пера» (ni puha ni pera)

yediden yetmişe - «от мала до велика» (ot mala do velika)

çok eskiden, Nuh zamanında kalma - «npu u̧ape горохе» (pri tsare gorohe)

iş avucumda - «дело в шляпе» (dela v şlyape)

devede kulak; nerede ise hiç yok - «кот наплакал» (kot naplakal)

mutluluktan havalara uс̧таk - «на седьмом небе» (na sed'mom nebe)

deneyimli, tecrübeli kişi - «собаку съел» (sabaku syel)

ӥzӥтӥ уе, bağını sorma - «дарёному коню в зубы не смотрят» (daryonoти konyu v zubı ne smotryat)

önayak olmak - «играть первую скрипку» (igrat' pervuуи skripku)

ne ekersen опи biçersen - «посеешь характер - пожнёшь судьбу» (poseyeș harakter-pojnyöş sudbu)

kaş yaparken göz çılkarmak - «медвежья услуга» (medvej'ya usluga)

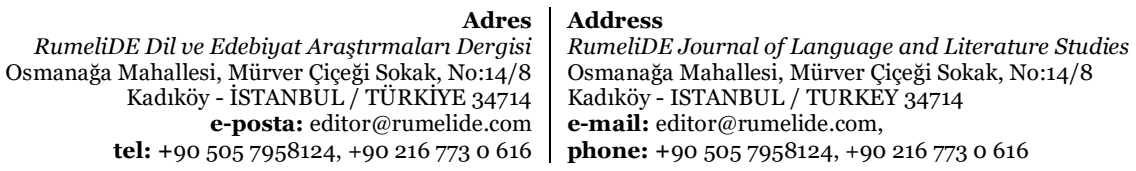


görmüş geçirmiş, feleğin çemberinden geçmiş kişi - «стреляный воробеŭ» (strelyanniy vorobey)

kirli çamaşırları ortaya dökmek - «выносить сор из избы» (vınasit’sor iz izbı)

başına buyruk - «вольная птица» (vol'naya ptitsa)

denizde kum onda para, çok zengin -«денег куры не клюют» (deneg kurı ne klyuyut)

ne idiği belirsiz bir șey - «черт знает что» (çyort znayet çto)

laf söyleyemez - «нечем крыть» (neçem krıt')

tek başına savaş olmaz - «один в поле не воин» (odin v pole ne voin)

sırra kadem bastı - «след простыл» (sled prostıl)

elekle su taşımak - «носить воду решетом»( nosit' vodu reșetom)

iğne atsan yere düşmеz - «яблоку негде упасть» (yabloku negde upast')

leb demeden leblebiyi anlamak - «ловить на лету» (lavit' na letu)

küçük ama güçlü cesur olmak - «мал да yдaл» (mal da udal)

kafadan atmak - «брать с потолка» (brat’s patalka)

dünyanın öbür исипda - «за тридевять земель» (za tridevyat' zemel')

Deyimleri çevirirken, deyimlerin duygusal bileşen değerlerinin mecaza dayandığı dikkate alınmalıdır. Bu nedenle, çeviri sırasında ifadenin duygusallığını iletmek için, mecazi temelini korumak gerekir.

Rusçada «ехать зайцем» (yehat zayçem) deyimi, 'kaçak, biletsiz seyahat etmek' ifadesinde kullanılır. Bu deyimdeki «заяц» (zayaç) - tavşan kelimesi korkunun imgesini oluşturur. Biletsiz kişi genel olarak ceza yazılmasından korkar ama yine de o şekilde yolculuk yapar. İmgeyi zihninde çizerken çevirmen kendi ana dilinde tam ya da benzer karşılığını bulabilir, eşdeğerin bulunamadığı durumlarda ise ilgili deyimin anlamını karşılıksız çevirmek durumundadır.

V.S. Vinogradov'un tanımına göre, eğer deyimin karşılığı erek dilde bulunmuyorsa, çevirmen ilkin şekli tutmak zorunda değil. Önemli olan deyimin biçimsel ve işlevsel görevini devretmektir. Tabi ki, çevirmen her zaman deyimleri karşılığını erek dilde deyim olarak bulmaya çalışıyor ancak deyim eş değeri erek dilde her zaman bulunmayabilir veya biçimsel özellikleri farklılık gösterebilir (Vinogradov,2004: 190).

Türkçe ve Rusça arasında kültürel yakın bir bağlantı bulunmadığı için her iki dilde de aynı anlam ve biçimde tam eşdeğer deyimlerin bulunması bazen oldukça zordur ve ekser deyimlerin karşılı̆̆ı bulunmamaktadır. Kültürler arası farklılıklardan kaynaklanarak, çeviri yaptığımız dil ile çeviri yapacağımız dil arasındaki kültürel uçurumların büyüklüğü, çeviri sorunların da çok olacağı anlamına gelmektedir.

Etnik-kültür içeriğin taşıyıcıları olan deyimleri doğru bir şekilde çevirmek çok zordur, çünkü çeviri sırasında deyimlerin rengini korumak önemlidir. Türkçe ve Rusça farklı coğrafyalarda geliştiği için yaşam

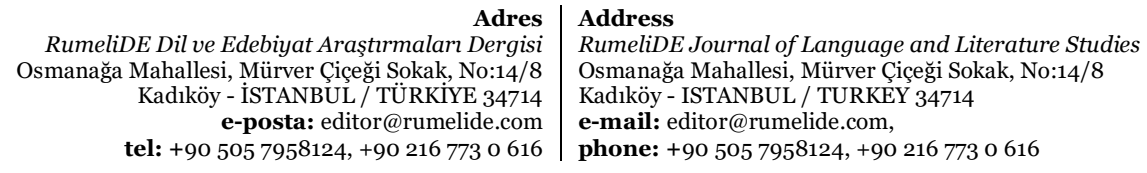


tarzları da farklıdır. Örneğin, Türk ve Rus kültürlerinin birbirinden çok farklı olmasından kaynaklı olarak, Türkçe deyimleri Rusçaya çevirirken, Türk halkının yaşam tarzı ile ilgili zorluklarla karşılaşılmaktadır. Bu yüzden, belli bir halkın yaşamından beslenen deyimler, diğer halklar tarafından her zaman anlaşılmayabilir. Başka ulus ve kültürlerin, deyimleri anlamadaki belli zorlukların nedeni bundan kaynaklanmaktadır.

Örneğin, "nazar değmek" (birebir çevirisi: «коснуться сзлаза» (kasnut'sya sglaza) - nazarın dokunması) "belli bir sebepten dolayı herhangi bir işin olmaması".

Bu veya başka bir milletin yaşam ve yaşam özgünlüğü, konuşma kurallarına yansımaktadır. Örneğin, "kolay gelsin" (birebir çevirisi: «пусть будет легко» (pust' budet legko) - kolay olsun) - "daha az zorluk çekme temennisinde bulunmak", "geçmiş olsun" (birebir çevirisi: «nусть будет в прошлом» (pust budet v proşlom) - geçmişte olsun) "hızlı bir şekilde iyileşme dileğinde bulunmak".

"Genellikle sözcük veya imgesel anlamlara sahip olan deyimlerin ait oldukları dildeki biçimleriyle başka dillere çevrilmesi mümkün değildir. Her iki durumda da çeviri diğer dilde bir anlam ifade etmeyebilir. Bunun sebebi olarak her deyimi kültür birikimi sonucunda oluştuğunu söyleyebiliriz" (İli, 2015: 120)

\section{Sonuç}

Deyimleri çevirirken karşılaşılan sorunları gramer, leksikal ve kültürel sorunlar olduğunu sıralaya biliriz.

Gramer sorunlar:

Çeviri yaptığımız kaynak dilden çeviri yapacağımız hedef dil arasındaki gramer farklılıklardır. Rusça ve Türkçe de cümle öğelerinin dizimi Rusça fiilî deyimlerde fiil isimden önce, Türkçe de ise aksine, isim fiilden önce gelmektedir. Örneğin, «лить как из ведра» - (lit' kak iz vedra) "bardaktan boşalırcasına yağmak"; «делать из мухи слона» (delat' iz muhı slona) -pireyi deve yapmak

Leksikal sorunlar:

Deyimleri çevirdiğimiz zaman karşılaşılan çok anlamlılık leksik zorluklardır. Deyimlerde çok anlamlılık birçok deyimin hem gerçek hem de mecaz anlam bildirmesi de çeviride karşılaşılan sorunlardan biridir. Örneğin, Türkçede ayağa kalkmak deyiminin 1) sağlığına kavuşmak (mecazi); 2) maddi sorunlardan kurtulmak (mecazi); 3) oturduğun yerden ayağa kalkmak (gerçek) anlamları vardır ki, Rusçaya çeviri yaptığımız zaman bu tür deyimlerin her bir anlamının dikkate alınması ve onlara uygun eşdeğer bulunması gerekmektedir.

Kültürel sorunlar:

Türk ve Rus halkları arasındaki kültürel farklılıklardan kaynaklanmaktadır. Örneğin, Türkçede 'okunaksız, kötü yazı' anlamında kullanılan "karınca duası gibi yazmak deyimi", Rusça eşdeğeri birebir çeviride 'tavuk pençesi gibi yazmak' olan «nишет как курица лапой» (pişet kak kuritsa lapoy) deyimidir. Rusçaya birebir çevirmek mümkün olmayıp, onların anlamına uygun eşdeğer aramak lazımdır. Bu tür kültürel sorunlar, çevirmenden kaynak ve hedef dilin gramer özellikleri ile birlikte, kültür ve tarihini de iyi bilmesini gerektiğini talep etmektedir.

Bu çalışmamızda konuya ilişkin bilimsel kaynaklardan yararlanarak ileri sürdüğümüz görüşleri özetleyecek olursak:

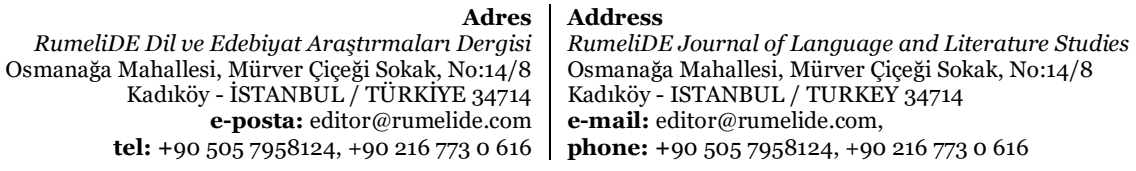


1) Çeviri etkinliği günümüzde bilimsel bir disiplinin, çeviri bilimin konusudur.

2) Çeviri bilim de kendi içinde özgün özelliklere sahip dallara ayrılmaktadır ve deyim çevirisi bu dallardan bir tanesidir.

3) Daha teknik deyimlerle dile getirilecek olursa genel çeviri kuramı özel çeviri kuramlarına ayrılır. Onlar da kendi aralarında iki büyük dal oluştururlar. Çalışmamızın konusu bakımında bunlarda ilki de somut iki dil arasında (Rusça-Türkçe-Rusça) karşılıklı olarak yapılan çeviri etkinliğidir.

4) Çalışmamızda somut iki dil arasında karşılıklı olarak deyim çevirisinin kendine özgü özellikleri örneklerle gösterilmiştir.

5) Son olarak söylemek istediğimiz, çeviri olgusunun bilimsel ve teknik bir etkinlik olmasının yanı sıra, aynı zamanda da yaratıcı bir etkinlik olduğu gerçeğidir.

Böylelikle, Rusça-Türkçe dilleri arasında deyimlerin çevirilerine ilişkin sorunları gidermek için çevirmen hem Rus hem de Türk dilinin deyim bilimine hâkim olması gerekmektedir. Bununla birlikte, çevirmenin bu iki ulusun tarih, yaşam ve kültüründen belirli bir bilgi haznesine sahip olması ve çeviri özelliklerini de derinden bilmesi gerekmektedir.

\section{Kaynakça}

Aksan, D. (1996). Türkçenin Sözvarlığı. Ankara, Engin.

Aksoy, Ö. A. (2000). Atasözleri ve Deyimler Sözlüğü. Ankara, İnkılâp.

Aygün, M. (2003). Türkçe ve Almanca'da "Göz" le İlgili Deyimlerin İncelenmesi. Frrat Üniversitesi Sosyal Bilimler Dergisi, Cilt: 13, Sayı:1, Elazı̆g

Coşkun, J. (2020). Rusçanın Yabancı Dil Olarak Öğretiminde Deyimlerin Öğretilmesi ve Önemi. 2 nd International Congress on Academic Studies in Philology s.143-149

Demirezen, M. (1991). "Çeviride Kayıplar Sorunu". Çeviribilim ve Uygulamaları Dergisi, S.1, s. 115-128

Göktürk, A. (2013). Çeviri, Dillerin Dili. 10. Baskı, İstanbul, Yapı Kredi.

Hengirmen, M. (1999). Dilbilgisi ve Dilbilim Terimleri Sözlüğü, Ankara,Engin.

İli, M. (2015). İngilizce Deyimlerin Türkçeye Çevirisinde Karşılaşılan Sorunlar ve Çözüm Yolları, Dicle Üniversitesi Sosyal Bilimler Enstitüsü Dergisi, Yıl-7

Komissarov, V,N. (1990). Teoriya Perevoda (lingivistiçeskiye aspektı), M.

Maslova, V.A. (2007). Lingvokulturologiya. Uçebnoye posobiye dlya studentov vısşih uçebnıh zavedeniy, Moskova, İzdatelskiy çentr Akademiya, s. 87

Ojegov, S.İ. (1986). Slovar Russkogo yazıka, Russkiy yazık, Moskova

Suçin, M. H. (2013). Öteki Dilde Var Olmak. İstanbul, Say.

Şanskıy, N. M. (1969). Frazeologiya Sovremennogo Russkogo Yazıka, Vısşaya şkola, Moskova

Teliya, V. N. (1966). Çto Takoe Frazeologiya?, Nauka, Moskova

Vardar, B. (1982). Dilbilimin Temel Kavram ve İlkeleri. Ankara, TDK Yayınları, 492

Vınogradov, V. S. (2004). Perevod: Obşie i Leksiçeskie Voprosı. Universitet knijnıy dom, Moskova

Yalçın,P. \& Büyüksaraç, Z. (2017). Atasözü ve Deyim Çevirilerinin Mona Baker Çeviri Stratejilerine Göre İncelenmesi. International Journal of Languages' Education and Teaching Volume 5, Issue 4, December, s.817-829

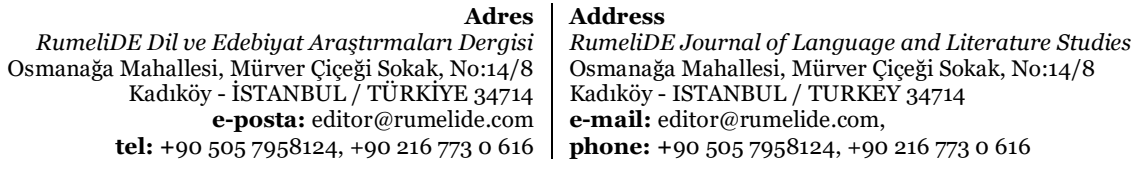


Yücel, F. (2013). Çeviribilimin Paradigmaları Çeviri Seçkisi. İstanbul, Çanakkale Kitaplığı Akademi Yayın. No:9

Adres $\mid$ Address

RumeliDE Dil ve Edebiyat Araştırmaları Dergisi $\quad$ RumeliDE Journal of Language and Literature Studies Osmanağa Mahallesi, Mürver Çiçeği Sokak, No:14/8 Osmanağa Mahallesi, Mürver Çiçeği Sokak, No:14/8 Kadıköy - ISTANBUL / TÜRKIYE 34714 Kadıköy - ISTANBUL / TURKEY 34714

e-posta: editor@rumelide.com e-mail: editor@rumelide.com,

tel: +90 505 7958124, +902167730616 $\mid$ phone: +90 505 7958124, +902167730616 